\title{
The impacts of land-use changes on the recovery of saltmarshes in Portugal
}

\author{
Diana Almeida ${ }^{\mathrm{a}, *}$, Carlos Neto $^{\mathrm{a}}$, Luciana S. Esteves ${ }^{\mathrm{b}}$, José Carlos Costa ${ }^{\mathrm{c}}$ \\ ${ }^{a}$ Centro de Estudos Geográficos, Instituto de Geografia e Ordenamento do Território, Universidade de Lisboa, Alameda da Universidade, Ed. Faculdade de \\ Letras, 1600-214 Lisboa, Portugal \\ ${ }^{\mathrm{b}}$ Faculty of Science and Technology, Bournemouth University, Talbot Campus, Fern Barrow, Poole, Dorset BH125BB, United Kingdom \\ ${ }^{c}$ Centro de Botânica Aplicada à Agricultura, Instituto Superior de Agronomia, Universidade de Lisboa, Tapada da Ajuda, $1349-017$ Lisboa, Portugal
}

\section{A R T I C L E I N F O}

Article history:

Available online

\begin{abstract}
A B S T R A C T
Human-induced land-use changes have resulted in loss and degradation of intertidal environments worldwide. Saltmarsh ecosystem dynamics in Portugal are greatly influenced by historic uses and consequent habitat degradation. This study uses an original approach combining vegetation surveys and spatial analysis of historic maps and aerial photographs to assess the effects of land use changes on saltmarshes in two areas in the Algarve, southern Portugal. Historical maps from c. 1800 and aerial photographs from 1958 to 2010 were analyzed to map saltmarsh ecosystems and quantify land-use changes in the Alvor estuary and Arade River. Between c. 1800 and 2010 more than half of saltmarshes were lost due to dyke building and saltmarsh reclamation for agriculture. In mid-1960s, the abandonment of reclaimed agricultural areas resulted in the recolonization of saltmarsh vegetation, which developed physically separated from natural marshes. In the study area, these saltmarshes naturally evolved into two distinct typologies: (1) enclosed mixed marshes, formed by patches of brackish, freshwater and some invasive species developing due to saline intrusion in areas where dykes have not been breached; and (2) tidally-restored saltmarshes, formed in areas where dyke breaching allows incursion of tides and development of a vegetation structure similar to natural saltmarshes. In Europe, passive (without human intervention) and active (artificially planned) saltmarsh restoration are important mechanisms for voluntary or statutory re-creation of intertidal habitats. Improved understanding of the factors influencing the development of distinct saltmarsh typologies through passive ecosystem recovery can provide new insights to support decision-making concerning intertidal habitat restoration. (c) 2014 Elsevier Ltd. All rights reserved.
\end{abstract}

\section{Introduction}

Human-induced saltmarsh loss is widespread along the world's temperate coasts (Moreira, 1986, 1992; Gu et al., 2007; Currin et al., 2008). Many studies have assessed the causes and consequences of saltmarsh loss (Eliot et al., 1999; Miller et al., 2001; Wu et al., 2002; Cahoon et al., 2006; Marfai and King, 2008), including in Portugal (Moreira, 1986; Ferreira et al., 2008). Degradation and loss of saltmarshes have major implications to their capacity of delivering ecosystem services, including: sediment accumulation; nutrients cycling; filtering of contaminants; wildlife habitat; flood regulation

\footnotetext{
* Corresponding author. Tel.: +351217940218.

E-mail addresses: diana-almeida@campus.ul.pt, dinevesalmeida@gmail.com (D. Almeida), cneto@campus.ul.pt (C. Neto), lesteves@bournemouth.ac.uk (L. S. Esteves), jccosta@isa.utl.pt (J.C. Costa).
}

and storm protection (Simas et al., 2001; Currin et al., 2008; Feagin et al., 2010; Gedan and Bertness, 2010; Kim et al., 2011). The extension, exposure and orientation of the saltmarsh in relation to the coast, and the vegetation cover and maturity level of the plant communities influence the capacity to provide ecosystem services.

Environmental changes driven by natural processes, such as sealevel rise, have greatly affected saltmarshes (Simas et al., 2001; Morris et al., 2002; Gedan and Bertness, 2010; Mensah and FitzGibbon, 2012). However, human occupation in coastal areas has affected saltmarhes natural dynamics (Reeve and Karunarathna, 2009). In Europe, since the Middle Age, artificial manipulation of these ecosystems often enhanced erosion rates and resulted in substantial transformations in saltmarsh composition, distribution and functions (Castillo et al., 2000; Mattheus et al., 2010; Gedan et al., 2011). These transformations increased saltmarshes vulnerability to environmental changes, reducing their natural adaptive capacity (French and Burningham, 2003; Gedan 
et al., 2009). The urban, touristic, industrial and agricultural uses along the Portuguese coast have severely prevented the chances of saltmarsh recovery (Moreira, 1992; Rolo, 2007).

Natural saltmarsh evolution and diversity have been widely studied (Moreira, 1987; Costa and Lousã, 1989; Leveuvre et al., 2000; Caçador et al., 2007; Deegan et al., 2012). More recently, studies have focused on vegetation cover and species richness in embanked areas (Kleyer et al., 2003; Robinson et al., 2004; Bonisa et al., 2005) and as a result of de-embankment (Garbutt and Wolters, 2008; Barkowski et al., 2009). Such studies describe the effects of human intervention on the characteristics and recovery of saltmarshes and are important to inform practices and policy concerning intertidal habitat creation (e.g. Habitat Directive objectives and/or to compensate for loss of protected areas) and their ability to deliver ecosystem services (Mossman et al., 2012; Spencer and Harvey, 2012). In southern Europe (e.g. Portugal, Spain and France), economic drivers led to the abandonment of agricultural practices in some areas, including coastal reclaimed land, creating opportunities for saltmarsh colonization (Boorman et al., 2002; Vélez-Martín et al., 2010).

This article assesses the effects of land use change on the evolution of secondary saltmarshes and describes the emerging distinct typologies using selected areas in the Algarve (Southern Portugal) as case study. A novel approach combining vegetation surveys and mapping of land-use changes based on analyses of historic maps and aerial photography is used here to assess how historic land uses (from 1800s to 2010) contribute to the development of different saltmarsh typologies. The article first identifies the effects of human activities on saltmarsh dynamics along the Alvor estuary and the Arade river mouth. Then results from spatial analysis of land use changes and vegetation surveys are used to identify the main typologies of recovered saltmarshes. The discussion focuses on the drivers influencing unmanaged saltmarsh recovery under a Mediterranean climate and highlights wider applications concerning the restoration of saltmarsh habitats. The article ends with a summary of the main conclusions concerning the effects of land-use changes on the typology and development of secondary saltmarshes.

\section{Study area}

The Alvor estuary (Ria de Alvor) and the marshes of the Arade river (and the tributary Ribeira de Boina) are located in the Portimão municipality (Algarve, southern Portugal, Fig. 1). The area has temperate Mediterranean climate, showing mean annual temperature around $17{ }^{\circ} \mathrm{C}$ (at Faro Airport, IGP, 2005) and annual mean precipitation at the coast between $400 \mathrm{~mm}$ and $500 \mathrm{~mm}$, with the wet season occurring from October to April (Ribeiro, 1987). Alvor is a tidal lagoon dominated by sandy sediments of maritime origin set in a mesotidal environment with little freshwater input. The Arade River mouth is a drowned river valley subjected to tidal influence from the mouth to $13 \mathrm{~km}$ upstream.

Human occupation in the study area began in the Neolithic (2 000-1600 BC). The Carthaginians and the Romans had introduced fish salting and salt exploitation as regular economic activities. In 715 BC the Arab occupation enhanced the economic importance of Portimão and Alvor, which were important seaports exporting products to the rest of the Arab empire (Vieira, 1911). The economic activities were based on activities undertaken at high marsh areas, including: fishing, bivalve gathering, sun-drying fish and fruit and extraction of salt in salt pans (Loureiro, 1909; Vieira, 1911).

The earthquake of 1755 and the associated major tsunami reconfigured the Portuguese coast (Dias, 2004). Records suggest that the tsunami wave entered $667 \mathrm{~m}$ inland in the area of Alvor altering the ebb delta morphology preventing tall ships to enter the estuary; saltmarshes were one of the most affected ecosystems (Loureiro, 1909). The tsunami resulted in a greater mobility of the Alvor estuary inlet, which threatened adjacent property and triggered the construction of dykes and embankments leading to saltmarsh reclamation (Pullam, 1988). The tsunami impact at the coast triggered a series of floods in the Arade River, in which the sea entered $14 \mathrm{~m}$ inland, causing siltation of the river mouth (Loureiro, 1909).

\section{Materials and methods}

Qualitative data sources were analyzed to understand the socioeconomic and environmental factors influencing saltmarsh evolution in the study area. The main sources of qualitative information included: parish records of population surveys and land registry; the genealogy of Algarve's landlords and noble families, in order to access the land use changes and acquisitions; and port authorities' records about damage caused by the earthquake. Historical documents allowed the reconstruction of the human occupation and the economic activities that have taken place in marsh areas, including land reclamation.
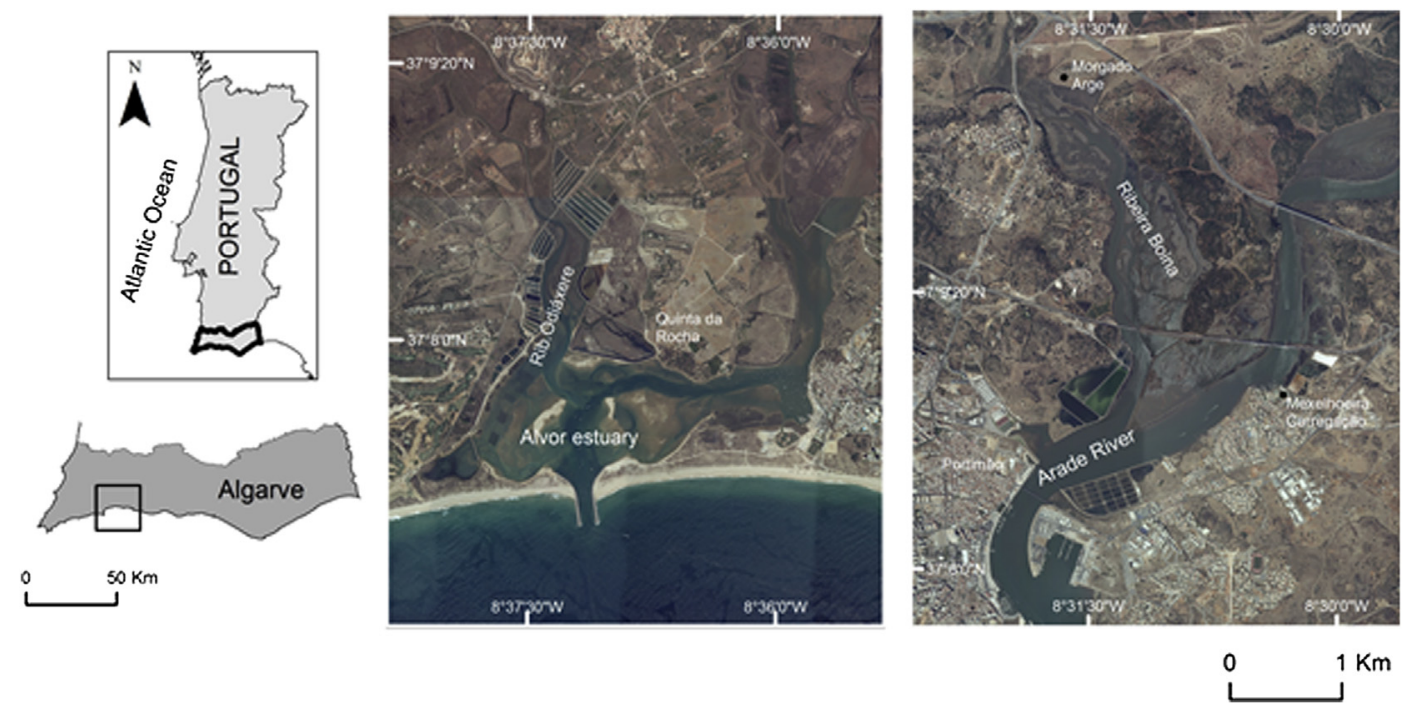

Fig. 1. The study area: Ria de Alvor and Arade River (Algarve, southern Portugal). 
Table 1

Cartographic data sources used in this study.

\begin{tabular}{|c|c|c|c|}
\hline Date & Chart type & Source & Information provided \\
\hline $1789-1800$ & $\begin{array}{l}\text { Segundo Plano Hidrográfico do Rio de Villa } \\
\text { Nova de Portimão }\end{array}$ & $\begin{array}{l}\text { Baltazar de Azevedo Coutinho, Eng. }{ }^{\circ} \text { Instituto } \\
\text { Geográfico do Exército - IGEOe }\end{array}$ & $\begin{array}{l}\text { High and low saltmarshes, mudflats, saltpans, } \\
\text { agriculture }\end{array}$ \\
\hline 1884 & $\begin{array}{l}\text { Carta de Portugal 1:100 000, No.36 (Military } \\
\text { Chart) }\end{array}$ & $\begin{array}{l}\text { Direcção Geral dos Trabalhos Geodésicos do } \\
\text { Reino, }\end{array}$ & Coastal configuration and saltmarshes position \\
\hline 1909 & Planta da Bahia do Porto de Lagos & $\begin{array}{l}\text { Loureiro, Adolfo (1904), Os Portos Marítimos de } \\
\text { Portugal, vol.5 (1904-1909) }\end{array}$ & Coastal configuration and saltmarshes position \\
\hline $\begin{array}{l}1922 \\
1923 \\
1930\end{array}$ & $\begin{array}{l}\text { Carta de Portugal 1:50 000, sheets 49D, 52a ; } 49 \mathrm{C} \\
\text { (Land Use Chart) }\end{array}$ & $\begin{array}{l}\text { Direcção Geral dos Trabalhos Geodésicos e } \\
\text { Topográficos }\end{array}$ & Wetlands, saltmarshes and irrigation schemes \\
\hline $\begin{array}{l}1950 \\
1951\end{array}$ & $\begin{array}{l}\text { Carta Agricola e Florestal 1:25 000, sheets 594, } \\
\text { 595, } 603\end{array}$ & Secretariado Geral da Agricultura & $\begin{array}{l}\text { Agriculture uses, land occupation and } \\
\text { transformation of saltmarshes }\end{array}$ \\
\hline $\begin{array}{l}1967 \\
1970\end{array}$ & $\begin{array}{l}\text { Carta de Portugal 1:100000, sheets 52, } 49 \\
\text { (Hydrographic Chart) }\end{array}$ & Instituto Geográfico e Cadastral & $\begin{array}{l}\text { Alterations in irrigation schemes, reservoirs, } \\
\text { mudflats, marshes and salt pans. }\end{array}$ \\
\hline $\begin{array}{l}1958 \\
1972 \\
1987\end{array}$ & Aerial photos & $\begin{array}{l}\text { Centro de Estudos Geográficos (1958) } \\
\text { Instituto Geográfico Português (IGP) }\end{array}$ & Land cover \\
\hline $\begin{array}{l}1995 \\
2005 \\
2010\end{array}$ & Ortophotomaps & Instituto Geográfico Português (IGP) & Land cover \\
\hline
\end{tabular}

The methodology applied here is an original approach specifically designed for this study. A combination of vegetation surveys and spatial analysis of historic maps and aerial photography is used to assess the effects of land-use changes on saltmarsh typologies in the study areas. The methods of the spatial analysis and vegetation surveys are detailed below.

\subsection{Spatial analysis}

Historical cartography was essential in the spatial analysis of changes in saltmarsh boundaries and extent. Spatial analysis of historic data was possible only for the Arade River due to lack of data sources with adequate quality for the Alvor estuary. Although a map from 1909 shows the area of the Alvor, it does not show features that allow georeferencing. Sources of spatial information used in this study are listed in Table 1. The hydrography chart covering the area of the Arade river (named then Villa Nova de Portimão) dated from the period $1789-1800$ is used here as a historic baseline for the photointerpretation and geoprocessing operations. The historic chart was georeferenced using ArcGIS 10 resulting in a root mean square error of $8.90 \mathrm{~m}$. This historic chart allowed clear identification of land cover types (Fig. 2a), such as: high and low marshes (indicated on the original map by the common name of the dominant species); salt pans were easily identified by their shape, name, and location in the edge of the high marsh; other agriculture activities showing in the chart were not object of analysis. Geoprocessing analysis resulted in a land cover map and a table showing the extent of saltmarsh areas (Table 2).

Analysis of aerial photos and ortophotomaps were also used to map the human occupation in the study area. The Portuguese Cartographic Institute has obtained aerial photographs covering areas of the Portuguese coast at intervals of approximately ten years. Aerial photographs covering the study area were obtained in 1958, 1972 and 1987. All maps and photographs were georeferenced using the Portuguese national coordinate system ETRS_1989_Portugal_TM06. Spatial analysis in ArcGIS 10 was undertaken to estimate areas of saltmarsh accretion, erosion and stability. Validation of photo-interpretation was undertaken during fieldwork, conducted at the same dates of the vegetation surveys described below.

\subsection{Vegetation data}

Floristic surveys were conducted in the following dates: 15-18 October 2012 (Alvor); 7-10 February 2013 (Arade); 23-25 March 2013 and 20-26 April 2013 (Alvor and Arade). Floristic surveys



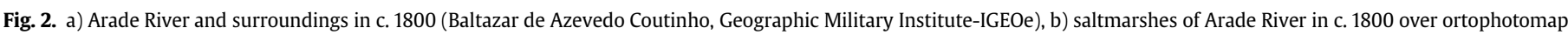
of 2010 . 
Table 2

Land-cover/land-use changes over 1958 to 2010 in Alvor and Arade.

\begin{tabular}{|c|c|c|c|c|c|c|c|c|c|c|c|c|}
\hline \multicolumn{13}{|l|}{ Covered area (ha) } \\
\hline \multirow[t]{2}{*}{ Land cover } & \multicolumn{2}{|l|}{1958} & \multicolumn{2}{|l|}{1972} & \multicolumn{2}{|l|}{1987} & \multicolumn{2}{|l|}{1995} & \multicolumn{2}{|l|}{2005} & \multicolumn{2}{|l|}{2010} \\
\hline & Alvor & Arade & Alvor & Arade & Alvor & Arade & Alvor & Arade & Alvor & Arade & Alvor & Arade \\
\hline Saltpans (working) & 39 & 34 & 48 & 38 & 43 & 40 & 30 & 36 & 30 & 12 & 29 & 12 \\
\hline Saltpans (abandoned) & 0 & 0 & 0 & 0 & 24 & 0 & 44 & 0 & 25 & 22 & 36 & 4 \\
\hline Aquaculture & 0 & 0 & 0 & 0 & 0 & 0 & 9 & 11 & 21 & 29 & 20 & 48 \\
\hline Saltmarsh early reclamation & 44 & 120 & 0 & 0 & 0 & 0 & 0 & 0 & 0 & 0 & 0 & 0 \\
\hline Saltmarsh in process of reclamation & 41 & 0 & 6 & 70 & 0 & 67 & 0 & 0 & 0 & 0 & 0 & 0 \\
\hline Salrmarsh (reclaimed) & 84 & 120 & 161 & 70 & 45 & 67 & 24 & 13 & 55 & 27 & 47 & 49 \\
\hline Saltmarsh (natural) & 182 & 196 & 73 & 129 & 69 & 111 & 55 & 109 & 65 & 85 & 72 & 118 \\
\hline Saltmarsh (dyked) & 0 & 48 & 35 & 66 & 5 & 5 & 10 & 17 & 5 & 17 & 24 & 25 \\
\hline Saltmash (recovered) & 0 & 0 & 0 & 0 & 0 & 0 & 1 & 24 & 1 & 1 & 16 & 14 \\
\hline Saltmash (eroded) & 0 & 3 & 1 & 0 & 3 & 2 & 1 & 0 & 0 & 0 & 0 & 13 \\
\hline Dykeland & 134 & 211 & 128 & 153 & 125 & 151 & 2 & 36 & 2 & 70 & 65 & 30 \\
\hline Dykeland (agriculture) & 0 & 0 & 0 & 0 & 117 & 0 & 123 & 0 & 14 & 0 & 0 & 17 \\
\hline Dykeland (abandoned) & 0 & 0 & 0 & 0 & 24 & 0 & 243 & 121 & 237 & 139 & 188 & 167 \\
\hline
\end{tabular}

were conducted following the abundance/dominance scores method (Braun-Blanquet, 1979) by using sampling quadrats of $2 \mathrm{~m}^{2}$ along selected transects. A total of 112 floristic surveys, amounting to 209 quadrats, were conducted in 15 randomly selected saltmarsh areas (Table 3). The botanical nomenclature followed the works of Castroviejo et al. (1986-2007), Franco (1971, 1984); Franco and Rocha Afonso (1994, 1998, 2003) and Rivas-Martínez (2005). The degree of presence (Braun-Blanquet, 1979) was calculated to evaluate the differences in species richness between saltmarsh areas (Table 4). The presence is estimated in percentages of a species and classified according to a chosen scale into a set of 'classes of presence'. The classes were defined as follows (Costa et al., 2009): $r$ (<6\%); + (6-10\%); I (11-20\%); II (21-40\%); III (41-60\%); IV (61$80 \%) ; V(>81 \%)$.

\section{Results}

The analysis of land cover c. 1800 (Fig. 2a) indicates that wetlands have been progressively urbanized in the area of Portimão (Fig. 2b). Geoprocessing of historic maps revealed that saltmarshes occupied an area of 242 ha c. 1800 . Analyses of aerial photography indicate that in 2010 the total area of saltmarshes was 118 ha. Therefore, $51 \%$ of saltmarshes in the Arade River mouth were lost between 1800 and 2010. Further analyses taking into account other areas along the Arade River indicate that in total $65 \%$ of the saltmarshes were lost between 1800 and 2010. Reclaimed areas along the river Arade correspond to excavated old marshes, filled with estuarine mud and protected from tidal influence, with the purpose to create land for agriculture. Estuarine muds, nutrient-rich, were used to fill the reclaimed saltmarsh and build dykes structures upstream the Boina and along the left shore of the Arade River (Vieira, 1911).

\subsection{Land-use changes between 1958 and 2010}

Land-use changes in the period 1958 to 2010 highlight major transformations in the wetlands (Fig. 3), especially concerning saltmarsh reclamation for diverse economic activities (Table 2) and natural ecosystem distribution and composition. Table 2 shows the distribution in area of the saltmarsh sub-types and land uses in the Alvor estuary and Arade River identified though geoprocessing and photointerpretation. Dykeland refers to areas enclosed by dykes and embankments, built to prevent tidal incursion.

One of the major land cover transformations was the saltpans abandonment. These complexes of salt production generally occupied large areas. The abandonment of the salt production occurred as the traditional method for food preservation became less important, decreasing significantly the commercialization and export of salt (Rau, 1951). As a result saltpans were transformed into aquaculture production units starting around the mid-1980s in the Alvor and in the early 2000s in the Arade. By 2010, about 59\% of saltpans were abandoned in the Alvor estuary and $85 \%$ in Arade river.

In 1958 natural saltmarshes occupied a slightly larger area in Arade River (196 ha) than in the Alvor (182 ha), this relative proportion was maintained throughout the studied period. The Agriculture Development Plan was responsible for a $90 \%$ of the

Table 3

Floristic surveys places by stage of saltmarsh transformation, location description and coordinates.

\begin{tabular}{|c|c|c|c|}
\hline Stage of saltmarsh transformation & River/Estuary & Name of the place (village or site) & Coordinates (WGS 84) \\
\hline (1) Natural saltmarshes & Arade & Marine of Mexelhoeira da Carregação & $\mathrm{N} 37^{\circ} 08.910^{\prime} \mathrm{W} 008^{\circ} 30.311^{\prime}$ \\
\hline (1) Natural saltmarshes & & Companheira site & $\mathrm{N} 37^{\circ} 09.586^{\prime} \mathrm{W} 008^{\circ} 31.376^{\prime}$ \\
\hline (1) Natural saltmarshes & & Arade tributary: Ribeira de Boina & $\mathrm{N} 37^{\circ} 10.280^{\prime} \mathrm{W} 008^{\circ} 31.861^{\prime}$ \\
\hline (3) Fragmented saltmarsh & Alvor & Right side of Odiáxere creek & $\mathrm{N} 37^{\circ} 07.991^{\prime} \mathrm{W} 008^{\circ} 37.440^{\prime}$ \\
\hline (2) Early reclamation & & West of the Alvor village & $\mathrm{N} 37^{\circ} 07.596^{\prime} \mathrm{W} 008^{\circ} 35.871^{\prime}$ \\
\hline (4) Dyked saltmarshes & Arade & Dyked marshes at the left side of Arade River & $\mathrm{N} 37^{\circ} 09.272^{\prime} \mathrm{W} 008^{\circ} 30.042^{\prime}$ \\
\hline (4) Dyked saltmarshes & & Morgado de Arge (Boina creek) & $\mathrm{N} 37^{\circ} 10.335^{\prime} \mathrm{W} 008^{\circ} 31.985^{\prime}$ \\
\hline (4) Dyked saltmarshes & & Companheira dykedland & $\mathrm{N} 37^{\circ} 09.615^{\prime} \mathrm{W} 008^{\circ} 31.372^{\prime}$ \\
\hline (4) Dyked saltmarshes & Alvor & Quinta da Rocha & $\mathrm{N} 37^{\circ} 08.056^{\prime} \mathrm{W} 008^{\circ} 36.939^{\prime}$ \\
\hline (6) Eroded saltmarshes & & Southwest Alvor estuary & $\mathrm{N} 37^{\circ} 07.325^{\prime} \mathrm{W} 008^{\circ} 38.091^{\prime}$ \\
\hline (4) Dyked saltmarshes & Arade & Companheira inland & $\mathrm{N} 37^{\circ} 09.656^{\prime} \mathrm{W} 008^{\circ} 31.382^{\prime}$ \\
\hline (5) Recovered saltmarshes & & Upstream left side Arade & $\mathrm{N} 37^{\circ} 09.696^{\prime} \mathrm{W} 008^{\circ} 29.992^{\prime}$ \\
\hline (5) Recovered saltmarshes & Alvor & Former agriculture dykeland upstream Alvor River & $\mathrm{N} 37^{\circ} 08.537^{\prime} \mathrm{W} 008^{\circ} 35.841^{\prime}$ \\
\hline (5) Recovered saltmarshes & & Maria Pires & $\mathrm{N} 37^{\circ} 08.607^{\prime} \mathrm{W} 008^{\circ} 35.464^{\prime}$ \\
\hline (6) Eroded saltmarshes & & Northeast Quinta da Rocha & $\mathrm{N} 37^{\circ} 08.185^{\prime} \mathrm{W} 008^{\circ} 37.119^{\prime}$ \\
\hline
\end{tabular}


Table 4

Degree of vegetation presence in each marsh typology according to the scale: r (<6\%); + (6-10\%); I (11-20\%); II (21-40\%); III (41-60\%); IV (61-80\%); V (>81\%).

\begin{tabular}{|c|c|c|c|c|c|c|c|c|}
\hline \multirow[t]{4}{*}{ Species } & \multirow{4}{*}{$\begin{array}{l}\text { Total surveys by saltmarsh typology } \\
\text { No. Surveys in relation to tidal level }\end{array}$} & \multicolumn{7}{|c|}{ Habitat } \\
\hline & & \multicolumn{3}{|c|}{ Natural saltmarsh (46) } & \multicolumn{3}{|c|}{ Tidally-restored saltmarsh (32) } & \multirow[t]{2}{*}{ Enclosed mixed marshes (34) } \\
\hline & & \multirow{2}{*}{$\frac{\text { Low }}{16}$} & \multirow{2}{*}{$\frac{\text { Medium }}{15}$} & \multirow{2}{*}{$\frac{\text { High }}{15}$} & \multirow{2}{*}{$\frac{\text { Low }}{10}$} & \multirow{2}{*}{$\frac{\text { Medium }}{12}$} & \multirow{2}{*}{$\frac{\text { High }}{10}$} & \\
\hline & & & & & & & & - \\
\hline & Number of taxa present & 10 & 17 & 27 & 9 & 14 & 14 & 35 \\
\hline Spartine & tima & III & & & & & & \\
\hline Scirpus & mus var. compactus & I & & & & & & $\mathrm{r}$ \\
\hline Atriplex & ata & + & & & & & & I \\
\hline Suaeda & & I & I & II & & & & \\
\hline Sarcocol & erennis & III & I & & VI & VI & & VI \\
\hline Sarcocol & rennis sub. alpini & $\mathrm{I}$ & II & & VI & VI & III & + \\
\hline Sarcocol & uticosa & I & III & II & $\mathrm{I}$ & III & & I \\
\hline Cistanch & ypaea & II & II & III & & II & + & II \\
\hline Halimio & tulacoides & V & V & II & VI & $\mathrm{V}$ & VI & + \\
\hline Puccinel & rica & & + & + & II & I & + & + \\
\hline Puccinel & Iritima & & $\mathrm{I}$ & + & + & & & \\
\hline Arthroct & macrostachyum & & + & II & & II & III & $r$ \\
\hline Suaeda & & & I & IV & & & & \\
\hline Spergulc & edia & & I & I & & & & \\
\hline Limoniu & arvense & & I & II & & & & $\mathrm{r}$ \\
\hline Spergulc & edia & & I & I & & & & \\
\hline Limoniu & ceolatum & & + & I & & + & & \\
\hline Juncus $n$ & nus & & II & & + & I & & + \\
\hline Limoniu & gare & & + & & & & & \\
\hline Limonia & monopetalum & & & III & & & II & \\
\hline Inula cri & des & & & II & & I & III & + \\
\hline Aster tri & I subs. pannonicus & & & I & & & & $\mathrm{r}$ \\
\hline Oxalis $p$ & rae & & & I & & & & I \\
\hline Salsola & ulata & & & I & & & & III \\
\hline Limoniu & usum & & & I & & & & \\
\hline Atriplex & & & & I & & & & \\
\hline Calendu & ensis & & & + & & & & $\mathrm{r}$ \\
\hline Carpobr & dulis & & & + & & & & $\mathrm{r}$ \\
\hline Elymus & & & & + & & & & $r$ \\
\hline Emex $s p$ & & & & + & & & & + \\
\hline Ferula $t$ & & & & + & & & + & VI \\
\hline Medicag & morpha & & & + & & & & $r$ \\
\hline Sonchus & imus & & & + & & & + & \\
\hline Franken & & & & + & $r$ & II & & I \\
\hline Scirpus & mus & & & & + & & & $\mathrm{r}$ \\
\hline Aster tri & & & & & & II & & \\
\hline Scorpiur & miculatus & & & & & I & III & $\mathrm{r}$ \\
\hline Elymus & tus & & & & & + & $\mathrm{I}$ & \\
\hline Artemisi & itima var galica & & & & & & + & II \\
\hline Juncus a & & & & & & & + & $\mathrm{r}$ \\
\hline Salicorn & osissima & & & & & & + & II \\
\hline Artemisi & pestris subs maritima & & & & & & & $r$ \\
\hline Atriplex & & & & & & & & $\mathrm{r}$ \\
\hline Cotula c & pifolia & & & & & & & VI \\
\hline Hypochc & adicata & & & & & & & I \\
\hline Lotus $\mathrm{cr}$ & & & & & & & & + \\
\hline Melilotu & talis & & & & & & & $\mathrm{r}$ \\
\hline Polypog & ritimus & & & & & & & II \\
\hline Salsola & & & & & & & & $\mathrm{I}$ \\
\hline Sedum s & & & & & & & & II \\
\hline
\end{tabular}

saltmarsh reclamation in both areas. Despite the decrease on natural saltmarshes between 1958 and 1995, a slight increase was observed in the subsequent years (Fig. 3 middle). The recovery dynamics started to be noticed in 1995 with an average of 9 ha/year of new saltmarshes in the Alvor and 13 ha/year in the Arade during 1995-2010. There was a great overall loss of saltmarsh areas in the period $1958-2010$ (61\% in the Alvor and 40\% in the Arade). However, the loss would have been even greater without the recovery of saltmarsh areas observed between 1995 and 2010, resulting in the creation of 18 ha of new saltmarshes in the Alvor and 39 ha in the Arade.

Along the Arade River 48 ha of saltmarshes were already dyked in 1958. In 1987 agriculture within dykelands grew the most causing a great decrease in saltmarsh extent within embanked land. Until 1987, the loss of dyked saltmarsh represented the total saltmarsh area that had been destroyed. Over the period 1958$2010,47 \%$ of saltmarshes were dyked along the Arade River. Only $19 \%$ of saltmarshes were diked in the Alvor estuary reflecting a more effective process of reclamation in Alvor.

Saltmarshes dynamics is not independent of other environmental and anthropogenic factors. Most changes in saltmarsh are associated with small local activities or development. For instance, the 13 ha of eroded saltmarshes quantified between 1995 and 2010 in the Arade River was caused by the construction of a touristic marina. Between 1958 and 2010, there was a net saltmarsh loss of 73 ha in the Alvor estuary, resulting from 98 ha of eroded 

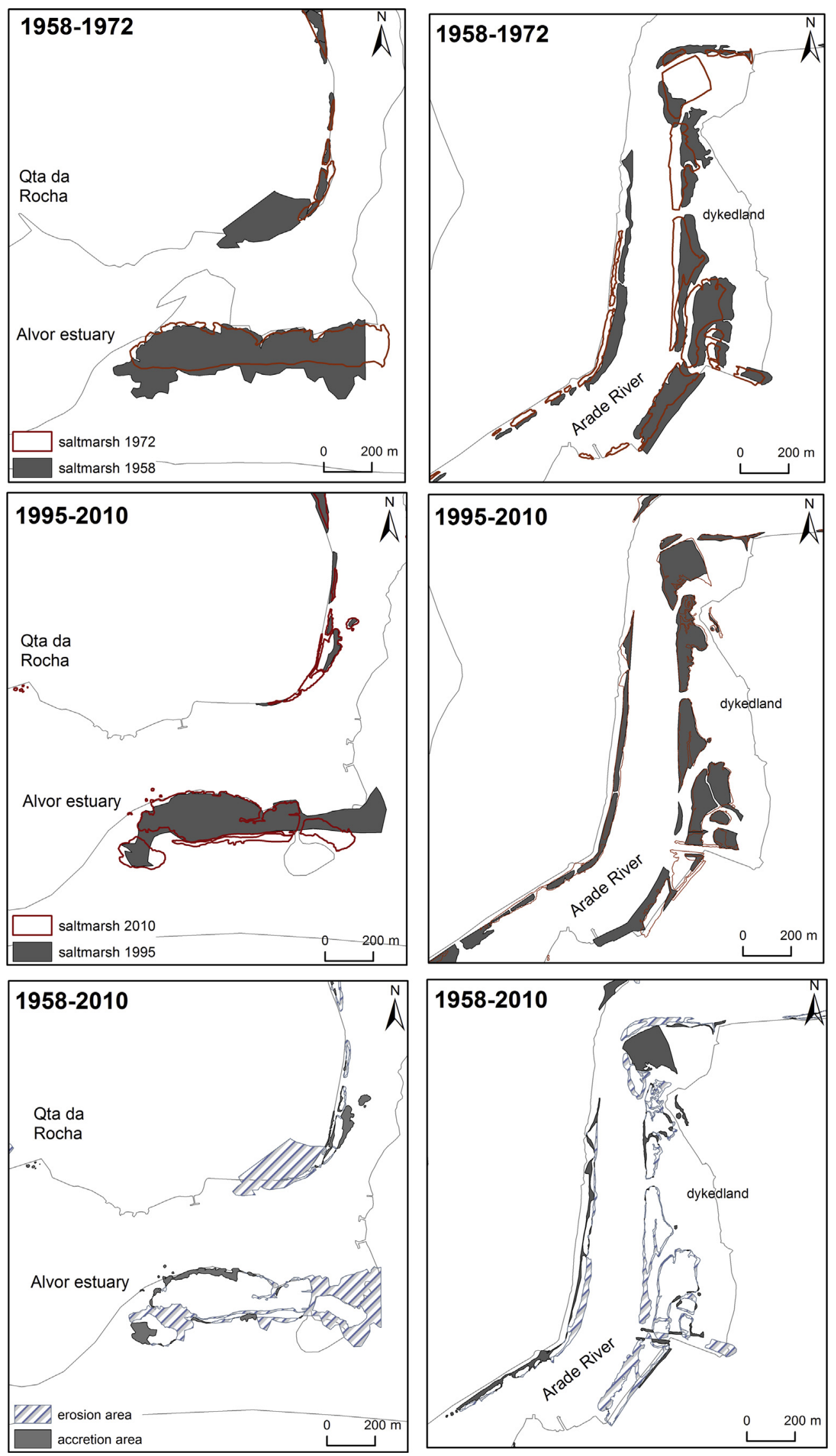

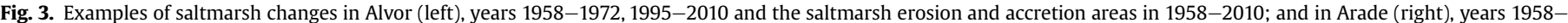
$1972,1995-2010$ and the saltmarsh erosion and accretion areas in 1958-2010. 
saltmarshes and 25 ha of restored saltmarshes. For the same period, the Arade River showed a net saltmarsh gain of 12 ha, resulting from 14 ha of eroded saltmarshes and 26 ha of restored saltmarshes.

\subsection{Saltmarshes typologies}

Land-use changes created a process of transformation in which natural marshes gave place to new sub-types (i.e. altered saltmarshes) and/or eventually were completely lost. Fig. 4 schematically represents the progressive transformation of saltmarshes caused by reclamation and restoration process, using as example an area along the left shore of Ribeira de Boina. Several marshes have disappeared through this process, at the same time that many other typologies emerged.

Based on photointerpretation of images dating from 1958, 1972, 1987, 1995, 2005 and 2010 and quarterly reports that accompanied the land reclamation process until 1987, six stages of transformation or saltmarsh sub-types were identified:

1. natural saltmarshes: all saltmarshes that were not dyked, destroyed or damaged;

2. early reclamation: the saltmarsh was dyked and started to fragment, usually observed in the period 1958-1972, when the Agriculture Development Plan was being implemented;

3. fragmented saltmarsh: at the final stages of the reclamation process, the saltmarsh is clearly fragmented and occupying a smaller area than in the early reclamation stage. The fragmented stage was observed until 1987; therefore, saltmarsh transformation from 'early reclamation' to 'fragmented' in the study area occurred in a time-frame of around 15 years.

4. dyked saltmarshes: saltmarshes are enclosed within embankments/dykes and completed isolated from tidal influence;

5. recovered saltmarshes corresponding to patches that were affected by land reclamation but were naturally recovering outside dyked areas; and

6. eroded saltmarshes, these refer to saltmarshes that were permanently lost.

In the study area, dyked saltmarshes naturally evolved into two distinct typologies based on their floristic structure: (1) enclosed mixed marshes, formed by patches of brackish, freshwater and some invasive species developing due to saline intrusion in areas where dykes have not been breached; and (2) tidally-restored saltmarshes, formed in areas where dyke breaching allows incursion of tides and development of a floristic structure similar to natural saltmarshes.

\subsection{Floristic characterization of different saltmarshes}

Table 3 lists the 15 locations where floristic surveys were conducted and indicates the dominant saltmarsh sub-type (or stage of transformation) present in each area. The surveys were conducted in randomly selected areas of $14.9 \mathrm{~m}^{2}$.

The degree of presence calculated in each of the 112 floristic surveys is shown in Table 4 for natural saltmarshes and the two typologies of diked saltmarshes identified in this study (i.e. tidally-restored and enclosed mixed). Surveys allowed differentiating the floristic structure and composition of a natural saltmarsh from the other typologies. The floristic composition of a natural saltmarsh indicates low, medium and high marshes clearly structured in relation to the tidal levels. The floristic composition of tidally-restored saltmarshes varies depending on the elevation in relation to the tidal range. As the tidal flow is confined by the breach, the volume of tidal flow and the relative distance from the dike breach determines whether certain areas are subjected to inundation. Scirpus maritimus, Halimione portulacoides and Sarcocornia perenis appear near the dyke breach (low marsh); Sarcocornia alpini, Sarcocornia fruticosa, Limonium algarvence are present at the medium marsh; Limonastrum monopetalium, Suaeda vera, Inula critmoides (high marsh), occur near the paths or the upper dykes. Enclosed mixed marshes are not subjected to tidal inundation.

Table 4 indicates a loss of biodiversity at tidally-restored saltmarshes in comparison with natural saltmarshes, as can be seen by the reduction in the number of taxa and species observed in the surveys. Natural saltmarshes have higher number of taxa in all low, medium and high marsh areas (in relation to the tidal range) than tidally-restored saltmarshes (Table 4). In both typologies, low marshes show considerably lower number of taxa than medium and high marshes (Table 4). Enclosed mixed marshes show a distinguished composition and structure influenced by saltwater intrusion. These marshes are marked by the dominance of freshwater over brackish species (as freshwater input from rainfall is sufficient to last throughout the winter) and the presence of invasive (Cotula coronopifolia, Carpobrotus edulis, Oxalis pes-caprae) and terrestrial species (Hypochaeris radicata, Polypogon maritimus, Lotus creticus, Sedum sediforme, Artemisia campestris subs. maritime).

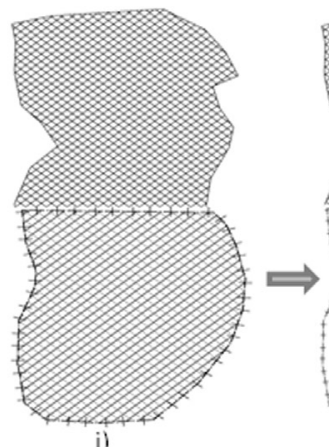

i)

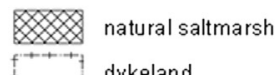

dykeland

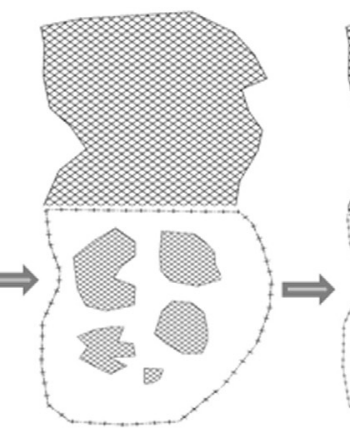

ii)

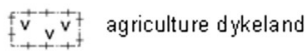

saltmarsh recovery

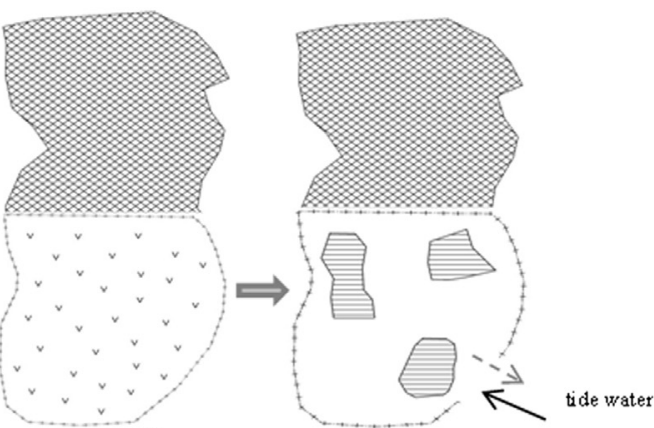

iii)

iv)

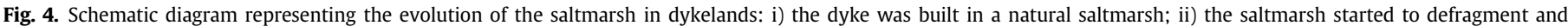

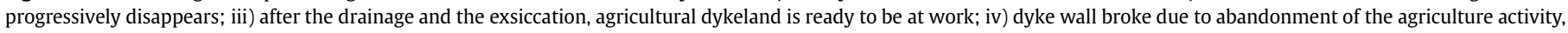
the tide water comes in, providing a low energy environment, allowing the marsh to evolve: an ecosystem recovery takes place. 


\section{Discussion}

Land-use changes commonly result in erosion and degradation of marshes (Bertness and Silliman, 2008). Natural saltmarshes are resilient to various disturbances in their ecology or ecosystems function (Roebeling et al., 2013) and they can respond positively to sea-level rise (Moreira, 1987). However, human occupation in coastal areas and the presence of hard engineering structures prevent inland migration of the saltmarsh ecosystems. Economic interests have been more important than the value or services offered by saltmarshes. Historically, coastal wetlands were seen as land available at low price with a privileged location.

The Alvor dykes were built in the early 17th century with the objective of supporting agricultural practices, e.g. by allowing freshwater farm irrigation from the Alvor tributaries to the Mexelhoeira Grande and Arão (Mariano, 2010). In Alvor, it was very common to artificially control tides along the tributary Ribeira de Odiáxere, in order to reclaim wetlands for agriculture. Two saltpans existed in Portimão; one at west of the urban center and the other in the north riverside, which progressively expanded towards Ribeira de Boina (Arade tributary).

Saltmarsh reclamation has occurred over a long period in the study area, but the greatest impacts arose by the implementation of the Portuguese Agriculture Development Plans (1953-1964), which targeted investments to stimulate economy. These Plans were implemented in two phases. The first phase (1953-1958) prioritized saltmarsh reclamation to create agricultural land through the construction of small embankments, clearing the original vegetation and irrigation with freshwater. These activities provided the leaching needed to avoid saltmarshes communities to grow. The second phase (1959-1964) focused on the exsiccation of dyked saltmarshes by trenching. Land reclamation in study area ceased mainly due to the failure of the Portuguese Agriculture Development Plans.

In many locations, the practices introduced by the Portuguese Agriculture Development Plans resulted in the destruction of marshlands beyond chances of restoration. Land reclamation for agricultural purposes was very successful on upstream saltmarshes, where freshwater streams feeding the Alvor estuary (i.e. Odiáxere, Arão, Penina) were able to reduced saltwater intrusion. Currently, marsh vegetation is not seen in these agricultural fields (agriculture dykeland). Recovery of saltmarshes are highly hindered in areas where the abandonment of commercial salt production has been replacement by aquaculture and in areas developed for urbantourist uses (Gedan et al., 2009).

In other locations, the great exsiccation works had limited success in creating agricultural areas. In the Alvor estuary, the influence of saltwater intrusion allowed enclosed mixed marshes to develop inside the dykelands. An important factor for the emergence of enclosed mixed marshes is the Mediterranean climate dry conditions, which favor salt intrusion by capillarity, as observed in the areas of Maria Pires and Quinta da Rocha in the Alvor estuary. In the Arade River, the failure of agricultural dykelands is related to the degradation of the embankments or the destruction of floodgates, after economic practices (e.g. grazing, agriculture or salt production) were abandoned. In these areas, the natural breaching of abandoned embankments restored tidal flow into the dykelands providing opportunities for tidally restored saltmarsh communities to develop. The restoration of saltmarsh communities was favored especially in areas of high sedimentation rates.

Surveys show significant differences in floristic composition between the primary (natural marsh) and the enclosed mixed marshes that grow inside dykelands. Enclosed mixed marshes are formed by patches of brackish species (Haliminone portulacoides, $S$. fruticosa, Arthrocnemun macrostachium), within freshwater communities (Puccinelia iberica, Juncus accutus, Scirpus compactus) presenting some invasive species ( $C$. coronopifolia, $C$. edulis, Cistanche philipaea, O. pes-caprae (e.g. observed at Maria Pires saltmarsh in the Alvor). Mossman et al. (2012) suggest that "it is unlikely that restored marshes with very different vegetation will be functionally equivalent" and discusses how floristic differences might affect different functions. Spencer and Harvey (2012) indicate that saltmarshes restored through active management (e.g. managed realignment) "may be significantly impaired" in their capacity to deliver "ecosystem services including biodiversity, climate regulation and waste processing".

Despite being impaired in their potential functionality when compared to natural saltmarshes, secondary saltmarshes (e.g. tidally-restored or enclosed mixed marshes) are still able to offer some ecosystem services. It is therefore required that further studies are able to quantify how functionally impaired restored saltmarshes might be and whether there are any ecosystem services they might not be able to provide. Nevertheless, especially for saltmarshes restored unmanaged, it might be more pertinent to compare their capacity to provide ecosystem services in relation to the land-use/land-cover type they have replaced (e.g. abandoned agricultural land), rather than their equivalence to natural habitats. For example, enclosed mixed marshes tend to be sheltered, providing conditions for birds and other animals to feed and refuge from predators; additionally, the saltmarshes enhance the ability to offer storm protection. These services are better provided by the restored saltmarshes than the previous land cover/use. Further understanding the evolution and functionality of restored saltmarshes and the ecosystem services they are able to provide is required to inform coastal managers on the benefits gained (and lost) from this unmanaged land use/cover change.

Regardless of the great land use transformations described here, natural saltmarshes continue to exist in both the Alvor and Arade study areas. Facing this great diversity of saltmarshes typologies, dealing with habitat management is truly a challenge. Enclosed mixed marshes and tidally-restores saltmarshes have different recovery rhythms mainly influenced by the previous land cover (economic activity) or by the stage of transformation at the time of abandonment. The saltmarshes typologies differentiation revealed extremely useful to categorize vegetation succession, which former studies fail to address. The analysis of the effects of past anthropogenic occupation revealed the resilience of saltmarshes and their ability to recover without artificial intervention.

\section{Conclusion}

Persistent human occupation and land-use changes in Portugal, rather than sea-level rise or other environmental changes, have caused the greatest impacts in coastal ecosystems in the last two centuries. This study quantified losses and gains in saltmarsh areas and identified typologies resulting from responses to land-use changes from 1800 to 2010 in the Arade River and Alvor estuary (Algarve, southern Portugal). A custom methodology involving a combination of spatial analysis (based on historic charts and aerial photographs) and vegetation surveys was used to quantify changes and identify saltmarsh typologies.

Land reclamation for agriculture was promoted by national policies in the 1950s and 1960s resulting in an overall loss of 763 ha (85\%) of saltmarshes in the study area between 1958 and 2010. Six stages of transformation were identified associated with the response of natural saltmarshes to land reclamation. In the mid1960 s, economic drivers led to the abandonment of agricultural practices allowing saltmarsh recovery in reclaimed areas. Local particularities resulted in the (unmanaged) development of two distinguishable saltmarsh typologies: (1) enclosed mixed marshes 
formed by patches of brackish, freshwater and some invasive species developed due to saline intrusion in areas where dykes have not been breached; and (2) tidally-restored saltmarshes formed in areas where dyke breaching allowed incursion of tides and the development of a floristic structure similar to natural saltmarshes.

Over the 1958-2010 period, saltmarsh recovery in the Arade River is dominated by tidally-restored saltmarshes, while the Alvor estuary enclosed mixed marshes dominate. Identifying the different typologies of secondary saltmarshes helps inform management practices aiming to enhance environmental benefits. For example, it is necessary to identify and quantify the capacity of different typologies to deliver ecosystems services in order to inform management efforts targeting enhancement of specific ecosystem services (e.g. carbon sequestration, flood risk management etc.). In this regard, for example, studies focusing on sediment dynamics in areas of tidally-restored saltmarshes and saltwater intrusion affecting enclosed mixed marshes would contribute to further understand the processes involved in the restoration of ecological functions in the study area and elsewhere.

The methodology used in this study proved appropriate to assess the response of saltmarshes to land-use changes. The six transformation stages and the two typologies of secondary saltmarshes identified in this study are likely to be found in other areas of Mediterranean climate (e.g. in Portugal, Spain and France). This methodology can be easily applicable to other locations worldwide providing land-use changes have been recorded through time (e.g. in historic charts).

\section{Acknowledgments}

This work was developed under the financial support of the Portuguese Foundation for Science and Technology (FCT reference SFRH/BD/77252/2011). We thank the support of Lieutenant Colonel José Bérger from the Gabinete de Estudos Arqueológicos da Engenharia Militar (GEAEM) in providing the cartographic material available at the Instituto Geográfico do Exército (IGEOe). In this regard we also thank Dr Paula Camacho (Direcção-Geral do Território, DGT) and Dr Sandra Domingues (Centre for Geographical Studies of the University of Lisbon).

\section{References}

Barkowski, J., Kolditz, K., Brumsac, H., Freund, H., 2009. The impact of tidal inundation on salt marsh vegetation after de-embankment on Langeoog Island, Germany-six years' time series of permanent plots. J. Coast. Conserv. 13, 185209. http://dx.doi.org/10.1007/s11852-009-0053-z.

Bertness, M.D., Silliman, B.R., 2008. Consumer control of salt marshes driven by human disturbance. Conserv. Biol. 22, 618-623.

Bonisa, A., Bouzille, J.-B., Amiauda, B., Loucougaray, G., 2005. Plant community patterns in old embanked grasslands and the survival of halophytic flora. Flora 200, 74-87. http://dx.doi.org/10.1016/j.flora.2004.06.002.

Boorman, L., Hazelden, J., Boorman, M., 2002. New salt marshes for old - salt marsh creation and management. In: Littoral 2002, the Changing Coast. EUROCOAST/ EUCC, Porto - Portugal, pp. 35-45.

Braun-Blanquet, J., 1979. Fitosociologia. In: Blume, H. (Ed.), Bases para el estudio de las comunidades vegetales (Madrid).

Caçador, I., Tibério, S., Cabral, H.N., 2007. Species zonation in Corroios salt marsh in the Tagus estuary (Portugal) and its dynamics in the past fifty years. Hydrobiologia 587, 205-211. http://dx.doi.org/10.1007/s10750-007-0681-y.

Cahoon, D.R., Hensel, P.F., Spencer, T., Reed, D.J., Mckee, K.L., Saintilan, N., 2006. Coastal wetland vulnerability to relative sea-level rise: wetland elevation trends and process controls. In: Verhoven, J., Beltman, B., Bobbink, R., Whigam, D. (Eds.), Wetlands and Natural Resource Management, Ecological Studies, vol. 190. Springer-Verlag Berlin and Heidelberg, pp. 271-292.

Castillo, J., Luque, C., Castellanos, E., Figueroa, M., 2000. Causes and consequences of salt-marsh erosion in an Atlantic estuary in SW Spain. J. Coast. Conserv. 6, 8996.

Castroviejo, S., Laínz, M., López González, G., Monserrat, P., Muñoz Garmendia, F., PAIVA, J., Villar, L. (Eds.), 1986-2007. Flora Iberica, vol. I-VIII, X, XIV, XV, XVIII, XXI. Real Jardín Botánico de Madrid, CSIC, Madrid.
Costa, J.C., Lousã, M., 1989. Communautes Psammophiles et Halophiles du "Ria de Alvor". Colloq. Phytosociol. XVIII, 119-135. Phytosociologie littorale et Taxonomie. Bailleul 1989.

Costa, J.C., Neto, N., Arsénio, P., Capelo, J., 2009. Geographic variation among Iberian communities of the exotic halophyte Cotula coronopifolia. Bot. Helvetica 119, 53-61. http://dx.doi.org/10.1007/s00035-009-0056-2.

Currin, C.A., Priscilla, A.E., Delano, C., 2008. Utilization of a citizen monitoring protocol to assess the structure and function of natural and stabilized fringing salt marshes in North Carolina. Wetl. Ecol. Manag. 16, 97-118.

Deegan, L., Johnson, D., Warren, S., Peterson, B., Fleeger, J., Fagherazzi, S. Wollheim, W., 2012. Coastal eutrophication as a driver of salt marsh loss. Research Letter. Nature 490, 388-392. http://dx.doi.org/10.1038/nature11533.

Dias, J.M., 2004. A história da evolução do litoral português nos últimos vinte milénios. In: Tavares, A.A., Tavares, M.J.F., Cardoso, J.L. (Eds.), Evolução Geohistórica do Litoral Português e Fenómenos Correlativos: Geologia, História, Arqueologia e Climatologia, pp. 157-170 (Lisboa).

Eliot, I., Finlayson, C.M., Waterman, P., 1999. Predicted climate change, sea-level rise and wetland management in the Australian wet-dry tropics. Wetl. Ecol. Manag. $7(1-2), 63-81$

Feagin, R.A., Martinez, M.L., Mendoza-Gonzalez, G., Costanza, R., 2010. Salt marsh zonal migration and ecosystem service change in response to global sea level rise: a case study from an urban region. Ecol. Soc. 15 (4), 1-14.

Ferreira, Ó., Dias, J.A., Taborda, R., 2008. Implications of sea-level rise for Portugal J. Coast. Res. 24 (2), 317-324.

Franco, J.A., 1971. Nova Flora de Portugal (Continente e Açores). Lisboa, Portugal. In: Lycopodeaceae-Umbelliferae, Author's edition, vol. I, p. 648.

Franco, J.A., 1984. Nova Flora de Portugal (Continente e Açores). Lisboa, Portugal. In: Clethraceae-Compositae, Author's edition, vol. II., p. 660.

Franco, J.A., Rocha Afonso, M.L., 1994. Nova Flora de Portugal (Continente e Açores) vol. III (Fasc. 1). Escolar Editora, Lisboa, Portugal, p. 181.

Franco, J.A., Rocha Afonso, M.L., 1998. Nova Flora de Portugal (Continente e Açores), vol. III (Fasc. 2). Escolar Editora, Lisboa, Portugal, p. 283.

Franco, J.A., Rocha Afonso, M.L., 2003. Nova Flora de Portugal (Continente e Açores), vol. III (Fasc. 3). Escolar Editora, Lisboa, Portugal, p. 198.

French, J.R., Burningham, H., 2003. Tidal marsh sedimentation versus sea-level rise: a southeast England estuarine perspective. In: Proceedings of Coastal Sediments '03, p. 14.

Garbutt, A., Wolters, M., 2008. The natural regeneration of salt marsh on formerly reclaimed land. Appl. Veg. Sci. 11, 335-344.

Gedan, K. Bromberg, Silliman, B.R., Bertness, M.D., 2009. Centuries of human-driven change in salt marsh ecosystems. Annu. Rev. Mar. Sci. 1, 117-141.

Gedan, K., Bertness, M.D., 2010. How will warming the salt marsh foundation species Spartina patens and its ecological role? Oecologia 164, 479-487 http:// dx.doi.org/10.1007/s00442-010-1661-x.

Gedan, Keryn B., Altieri, Andrew H., Bertness, Mark D., 2011. Uncertain future of New England salt marshes. Mar. Ecol. Prog. Ser. 434, 229-237, 7 (1-2): 63-81.

Gu, D., Zhang, Y., Fu, J., Zhang, X., 2007. The landscape pattern characteristics of coastal wetlands in Jiaozhou Bay under the impact of human activities. Environ. Monit. Assess. 124, 361-370.

Instituto Geográfico Português (IGP), 2005. Atlas Do Ambiente, 1a Edição, p. 307 Lisboa.

Kim, D., Bartholdy, J., Jung, S., Cairns, D., 2011. Salt marshes as potential indicators of global climate change. Geogr. Compass 5 (5), 219-236.

Kleyer, M., Feddersen, H., Bockholt, R., 2003. Secondary succession on a high salt marsh at different grazing intensities. J. Coast. Conserv. 9, 123-134.

Leveuvre, J.C., Bouchard, V., Feunteun, E., Grare, S., Laffaille, P., Radureau, A., 2000 European salt marshes diversity and functioning: the case study of the Mont Saint-Michel bay, France. Wetl. Ecol. Manag. 8, 147-161.

Loureiro, A., 1909. 1904. Os Portos Marítimos de Portugal e Ilhas Adjacentes. In: O porto de Alvor e de Lagos, vol. 5. Imprensa Nacional, Lisboa.

Marfai, M., King, L., 2008. Potential vulnerability implication of coastal inundation due to sea level rise for the coastal zone of Semarang City, Indonesia. Environ. Geol. 54 (6), 1235-1245.

Mariano, João, 2010. Mariscadores, Ria de Alvor: histórias de um lugar. Câmara Municipal de Portimão, p. 135.

Mattheus, C., Rodriguez, A., McKee, B., Currin, C., 2010. Impact of land-use change and hard structures on the evolution of fringing marsh shorelines. Estuar. Coast. Shelf Sci. 88, 365-376.

Mensah, K., FitzGibbon, J., 2012. Responsiveness of Ada Sea Defence Project to salt water intrusion associated with sea level rise. J. Coast. Conserv.. http:// dx.doi.org/10.1007/s11852-012-0219-y.

Miller, W.D., Neubauer, S.C., Anderson, I.C., 2001. Effects of sea level induced disturbances on high salt marsh metabolism. Estuaries 24 (3), 357-367.

Moreira, M.E., 1986. Man-made disturbances of the Portuguese Salt-marshes. Thalassas 4 (51), 43-47.

Moreira, M.E., 1987. Estudo Fitogeográfico do Ecossistema de Sapal do Estuário do Sado. Finisterra XXII (44), 247-296.

Moreira, M.E., 1992. Recent saltmarsh changes and sedimentation rates in the Sado estuary. J. Coast. Res. 8 (3), 631-640.

Morris, J., Sundareshwar, P., Nietch, C., Kjerfve, B., Cahoon, D., 2002. Responses of coastal wetlands to rising sea level. Ecology 83 (10), 2869-2877.

Mossman, H.L., Davy, A.J., Grant, A., 2012. Does managed coastal realignment create saltmarshes with 'equivalent biological characteristics' to natural reference sites? J. Appl. Ecol. http://dx.doi.org/10.1111/j.13652664.2012.02198.x. 
Pullam, R.A., 1988. A Survey of the Past and Present Weatlands of Western Algarve, Portugal. In: Liverpool Papers in Geography, vol. 2, p. 99.

Rau, Virgínia, 1951. A exploração e o comércio do sal de Setúbal. Estudo de História económica, Lisboa, p. 207.

Reeve, D., Karunarathna, H., 2009. On the prediction of long-term morphodynamic response of estuarine systems to sea level rise and human interference. Cont. Shelf Res. 29, 938-950.

Rivas-Martínez, S., 2005. Notions on dynamic-catenal phytosociology as a basis of landscape science. Plant Biosyst. 139 (2), 135-144.

Ribeiro, O., 1987. Geografia de Portugal. I .A Posição Geográfica e o Território. Edições João Sá da Costa, Lisboa vol. XXII, p. 334.

Robinson, S., van Proosdij, D., Kolstee, H., 2004. Change in dykeland practices in agriculture saltmarshes in Cobequid Bay, Bay of Fundy. In: BoFEP Conference Proceedings, pp. 1-9.

Roebeling, P., Costa, L., Magalhães-Filho, L., Tekken, V., 2013. Ecosystem service value losses from coastal erosion in Europe: historical trends and future projections. J. Coast. Conserv.. http://dx.doi.org/10.1007/s11852-013-0235-6.
Rolo, T., 2007. Intervenção no sapal oeste da vila de Alvor: um exemplo de recuperação? Dissertação para a obtenção do grau de Mestre em Biologia e Geologia Especialização em Educação. Faculdade de Ciências do Mar e do Ambiente, Universidade do Algarve, Faro, p. 133. Master Thesis.

Simas, T., Nunes, J., Ferreira, J., 2001. Effects of global climate change on coastal salt marshes. Ecol. Model. 139, 1-15.

Spencer, K.L., Harvey, G.L., 2012. Understanding system disturbancd and ecosystem services in restored saltmarshes: integrating physical and biogeochemical processes. Estuar. Coast. Shelf Sci. 106, 23-32.

Vélez-Martín, A., Luquei, C., Coca, M., Davy, A., Castellanos, E., 2010. Restoration of na old agricultural estate in Doñana National Park (SW Spain): a six-year vegetation study of a transformed marsh. In: Proceedings 7th European Conference on Ecological Restoration Avignon, France, 23-27/08/2010 1.

Vieira, Padre J.G., 1911. Memória Monográfica de Portimão, edição na integra de 1996 pela Junta de Freguesia de Portimão, p. 105.

Wu, S., Yarnal, B., Fisher, A., 2002. Vulnerability of coastal communities to sea-leve rise: a case study of Cape May County, New Jersey, USA. Clim. Res. 22, 255-270. 